Areh. Mikrobiol. 66, 203-219 (1969)

\title{
Observations on Some Cellulosic Chytridiaceous Fungi*
}

\author{
IRINEO J. DOGMA, JR.** \\ Department of Botany, University of Michigan \\ Ann Arbor, Michigan U.S.A. \\ Received February 7, 1969
}

\begin{abstract}
Summary. Two new species of Endochytrium, E. multiguttulatum and E. cystarum, are described. Nephrochytrium buttermerense Willoughby is transferred to Diplophlyctis under the binomial Diplophlyctis buttermerense (Willoughby) comb. nov. Morphologic and developmental information on an incompletely known fungus, possibly a Solutoparies, and on other previously known cellulosic chytrid species are also given.
\end{abstract}

Many interesting chytridiaceous fungi have come to light since a continuing investigation of the phycomycetous flora of the Douglas Lake region (Michigan) and vicinity was initiated by SPARRow (1952) in the summer of 1948. To summarize, a total of nineteen new chytrid species and one new variety of an algal parasite have been reported from the area, together with a rich file of information on numerous previously described forms occurring in various habitats and populating a wide variety of substrata (Sparrow and Barr, 1955; Patersor, 1956; JoHns, 1956). A number of incompletely known forms have also been noted (Sparrow and Koch, 1959; Sparrow, Paterson, and Johns, 1965). During the summers of 1967 and 1968 further studies were made on the chytrid flora of the area, and it is the purpose of this paper to report on some of these minute fungi captured on such cellulosic substrata as lens paper, onion skin, and cellophane. Two of them belong to the genus Endochytrium and are described here as new. Another one, Nephrochytrium buttermerense WuLougHBY (1962 b), is herein transferred to Diplophlyctis under the binomial Diplophlyctis buttermerense (Willoughby) comb. nov.

* Additions to the Phycomycete Flora of the Douglas Lake Region. VII.

A major portion of this work was carried out at the Biological Station, University of Michigan in the Summers of 1967 and 1968 under a NSF grant-in-aid.

** The author expresses his gratitude to Prof.F.K. Sparkow for his continuing guidance and helpful criticisms of the manuscript; to Dr. H. Thrers, Messrs. D. Farr and W. Patrick, Misses. N. Orlido and Z. Toquero, and Mr. and Mrs. A. QutMro for providing soil samples; and to Mr. D. R. RExnolds for supplying several leaf litter samples collected during his Sigma Xi-sponsored trip in Southeast Asia in 1967. The Latin diagnoses were kindly provided by Rev. ERNESTo O. $J_{A-}$ VIER, S. J. 
Additional observations on materials from other states in the country or from foreign countries-Singapore, Burma, the Philippines, Canada, etc.-were freely drawn upon when these were of direct relevance to the organisms being discussed.

\section{Endochytrium multiguttulatum sp. nov.}

Sporangium endobioticum, globosum, $83.0-150.0 \mu$ in diam., piriforme, $15.0-135.0 \mu$ in altitudine et $9.0-112.0 \mu$ in amplitudine, vel irregulare; eius dissepimentum primo fit aurobrunneum vel melleum et postea crustaceum in maturitate; formatum per augmentum partis distalis tubi germinalis, pars proxima huius tubi germinalis saepe persistat ut crassitunicata appendix, $5.0-18.0 \mu$ $\times 2.0-10.0 \mu$, pileata a parte persistente involucri zoospori, $2.0-4.0 \mu$ in diametro. Rhizoidea quae oriuntur juxta involucrum zoosporicum saepe sunt extramatricalia et longa. Zoospori globosi, 6.0-7.0 $\mu$ in diam., cum 5-10 globulis et flagello e latere formato et ad posterum tendente, $38.0-40.0 \mu$ longitudine. Hi zoospori liberati sunt simul quando operculum, $3.0-22.5 \mu$ in diam., persistens dehiscit in 1-4 papillis vel tubis emittentibus. Endooperculum et vesica absunt. Sporae quiescentes natae sunt sicut sporangia, globosae, $13.5-38.0 \mu$ in diam., vel late ellipsoideae, $30.0-38.0 \mu \times 20.0-22.0 \mu$, cum $4.5 \mu$ densitate, cum dissepimento fusco-aureo colore et cum multis undulationibus demissis, obtusis vel acribus; germinatio non observata.

Sporangium endobiotic, usually large and coarse, spherical, 83.0-150.0 $\mu$ in diameter, pyriform, $15.0-135.0 \mu$ high by $9.0-112.0 \mu$ broad, or irregular, the wall smooth, colorless at first, soon thickening to $1.3-1.7 \mu$, becoming goldenbrown or amber and crusty with age; formed by the enlargement of the distal portion of the germ tube of an encysted zoospore, the proximal portion of the germ tube usually persisting as a thick-walled, $5.0-18.0 \mu \times 2.0-10.0 \mu$ appendage capped by a portion of the persistent, $2.0-4.0 \mu$ in diameter zoospore case. Rhizoids arising near the zoospore case, mostly extramatrical, extensive, wavy, coiling, or twisting, up to $23.0 \mu$ broad at the point of origin, with thick, golden-brown wall, trabeculate at the proximal and vacuolate at the distal end. Zoospores hyaline, spherical, $6.0-7.0 \mu$ in diameter, with five to ten minute refractive globules, and a laterally inserted, posteriorly directed, 38.0-40.0 $\mu$ long flagellum which is retracted by vesiculation; released en masse by the dehiscence of convex, $3.0-22.5 \mu$ diameter opercula surmounting one to four short papillae or prominent discharge tubes $10.0-142.0 \mu \times 7.0-27.0 \mu$; quiescent for some time at the orifice and imbedded in the gelatinous, extruded substance formed beneath the operculum. Vesicle and endo-operculum not formed. Resting spores borne like the sporangium, spherical, 13.5-38.0 $\mu$ in diameter, or broadly ellipsoid, $30.0-38.0 \mu \times 20.0-22.0 \mu$, with $4.5 \mu$ thick golden-brown walls with numerous low, sharp or blunt, bullations; germination not observed.

On lens paper, cellophane, and onion skin bait in dish cultures of submerged samples of decayed Sphagnum and other plant debris, Gates' Bog (type locality), 15 July, 1967; Sphagnum bog, west side of Dingman's Marsh, 5 August, 1967; Smith's Bog, 12 July, 1968, all in Cheboygan Co., Michigan, U.S.A.

The assigning of this huge bog chytrid to its proper genus has proved to be a difficult task. Its outward appearance and multiguttulate zoospores are strikingly reminiscent of Karlingiomyces granulatus (Karling) Sparrow (Karding, 1947), but it differs from this fungus by 
its endobiotic habit and localized insertion of the rhizoidal axes near the persistent and thickened portion of the zoospore case (Fig. 14). It is also suggestive of the genus Nephrochytrium. The thickened proximal portion of the germ tube, however, is not regarded here as an apophysis, since its extent is dependent upon the depth at which the developing sporangium proper is imbedded in the substratum. (Figs. 7-17). It is often reduced to a short process that is continuous with and not separated from the sporangium proper by a cross wall. Indeed, this shortened germ tube is detectable primarily by the thickened zoospore case that caps it (Figs. 10-11, 22-23). When the germ tube is more pronounced and separated from the sporangium proper by a cross wall, it remains functional, together with the persistent zoospore case, as a part of the rhizoidal system that bridges that gap between the deeply imbedded sporangium proper and the extramatrical rhizoids (Figs. 14-16, 20).

The localized insertion of the rhizoidal axes, usually not more than two or three, near the zoospore case is a distinctive feature of $E$. multiguttulatum and resembles somewhat the situation found in Truittella setifera KaRLIng (1949). Fig. 21 shows an empty sporangium with fine, hair-like processes arising directly from the thickened remnant of the zoospore cyst. Such processes serve as the rhizoidal system of the otherwise rhizoidless sporangium, in contrast to the richly branched ones arising from several places on the sporangium of $T$. setifera. In many instances, the lateral branches of a main rhizoidal axis coiled around another such axis in a fashion reminiscent of the antheridial branches coiling around the hyphae of Achlya proliferoides of the Saprolegniaceae.

The type of development and growth habit of WسLOUGHBY's (1964) Cylindrochytridium endobioticum is identical with that of the Michigan fungus, except that it has a smaller zoospore body $(4.5-5.5 \mu$ in diameter), a shorter posteriorly attached flagellum (22-25 $\mu$ long), and a sporangium in which "an exit tube is never present". A similar generic disposition for the Michigan fungus is tempting, but here, as well as in $C$. endobioticum, the sporangial initial and not the rhizoidal system is laid down first (Figs. 3-9). A reverse situation is true in the development of Cylindrochytridium. Furthermore, its most diagnostic feature, namely, catenulation of the rhizoids (KARLING, $1941 \mathrm{a}$; WHIFFEN, 1941, pl. 8, Fig. 13) is lacking in the present fungus and in C.endobioticum. Finally, in the Michigan fungus the germ tube, as has been noted earlier, may be continuous with the sporangium proper, and its prominence is dependent upon the degree of intramatricality of the developing sporangium. Under these circumstances, therefore, special emphasis is given to the Entophlyctis-type of thallus development in the present fungus, to its non-apophysate sporangium and resting spore (Figs. 24, 25), 

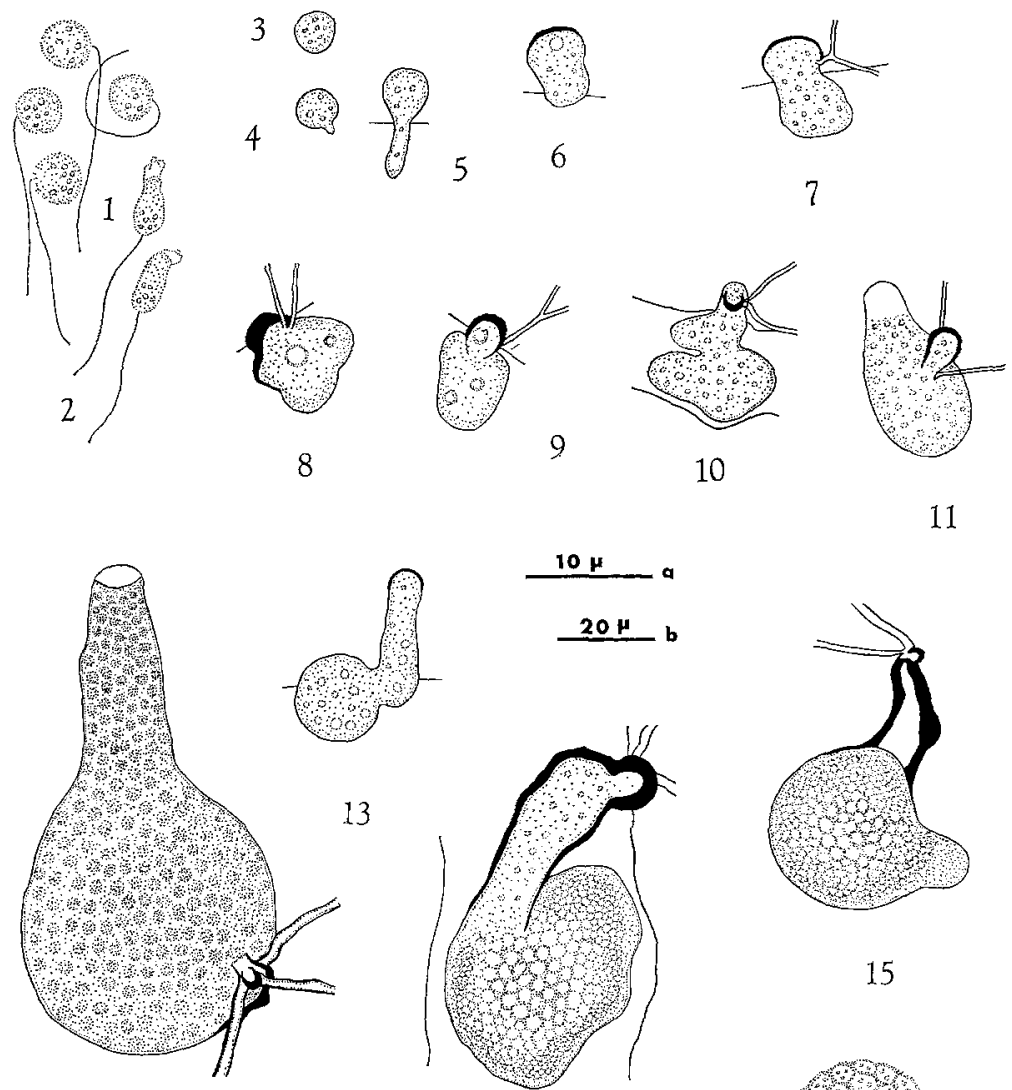

12

14
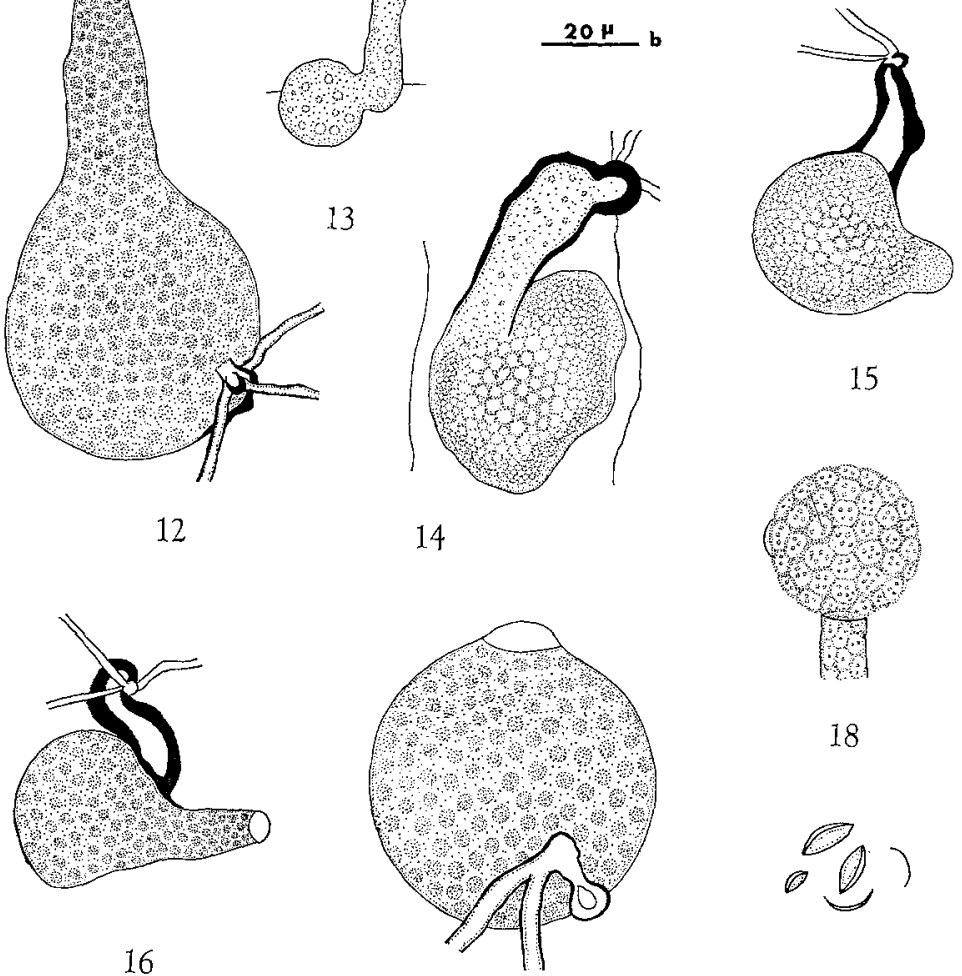

15

16
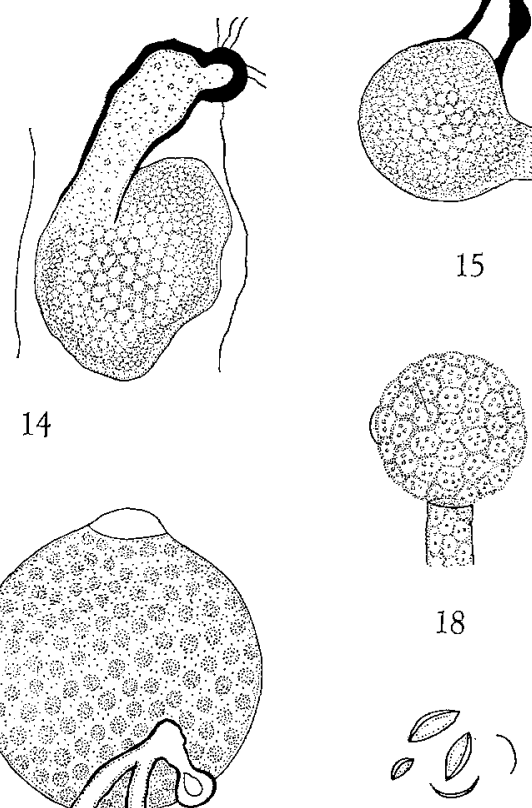

19

Plate I

17

Explanation of Plates. All drawings were made with the aid of a Spencer camera lucida, except Fig. 59 which is a diagrammatic representation from a cotton bluestained preparation 
and to the essentially endobiotic habit of its thallus. Accordingly, this unusually large bog chytrid seems best accomodated in Endochytrium.

Endochytrium multiguttulatum is distinct from all other known species of the genus by its multiguttulate zoospores with laterally inserted, but nonetheless posteriorly directed flagella (Figs. 1-2), and by its extramatrical rhizoids inserted locally near the persistent portion of the zoospore case. All efforts to isolate this chytrid in pure culture on Emerson's (1941) YpSs medium and on yeast extract-dextrosepeptone-bog water agar medium have thus far been unsuccessful.

Phlyctochytrium furcatum SPARRow (1966) was found parasitizing the sporangia of the Endochytrium isolate from Dingman's Marsh. This confirms indirectly the potentiality of this interesting chytrid towards what Sparrow termed "cannibalism". A species of Rhizophydium and an endobiotic form, perhaps an Olpidium, were found attacking the sporangia of the isolate from Smith's Bog.

\section{Endochytrium cystarum sp. nov.}

Sporangium endobioticum, achromaticum, tenuitunicatum, laeve, globosum, $13.5-90.0 \mu$ in diam., ovale vel irregulare, $24.0-75.0 \mu$ in altitudine et $18.5-54.0 \mu$ in amplitudine; affixum ad epibioticum involucrum zoosporicum per tubum germinis. Rhizoidea male evoluta, delicata, orientia ab 1-4 loca in sporangio, aliquando absentia. Zoosporae globosae, $2.2-2.6 \mu$ in diam., cum $0.6 \mu \mathrm{diam}$. globolo centrali, corpus arcuatum et cum flagello posteriore $17.0 \mu$ longitudine; liberata simul quando $4.0-6.0 \mu$ in diam. operculum dehiscit in $1-5$ papillis vel tubis emittentibus. Endooperculum et vesica absunt. Sporae quiescentes natae sunt sicut sporangia, globosae vel ovalae, $15.0-23.5 \mu \times 10.0-13.5 \mu$ brunneoalbae, cum aut sine spinis obtusis aut tuberculis $2.0-7.0 \mu \times 1.5-2.0 \mu$; germina tio non observata.

Sporangium endobiotic, hyaline, smooth, thin-walled, spherical, 13.5-90.0 $\mu$ in diameter, oval or irregular, $24.0-75.0 \mu$ broad by $18.5-54.0 \mu$ high; formed by the enlargement of the germ tube; attached to a persistent, epibiotic, thinwalled, colorless $2.0-2.5 \mu$ diameter zoospore case by a $3.0-15.0 \mu$ long germ tube. Rhizoids depauperate, poorly developed, arising from one to four places on the surface of the sporangium, sometimes lacking, very delicate, thin-walled, colorless, simple or branched twice, up to $2.5 \mu$ broad at the point of origin. Zoospores hyaline, spherical, $2.2-2.6 \mu$ in diameter, with a small centric globule $0.6 \mu$ in diameter, a faint arc-like body (nuclear cap?), and a posteriorly attached

Plate I. Figs.1-19. Endochytrium multiguttulatum n. sp. Fig. 1, zoospores in active stage showing laterally inserted flagella and multiguttulate content; Fig.2, amoeboid zoospores with anterior pseudopodia and trailing, passive flagella; Figs.3-5, germination of encysted zoospore; Figs.6-12, thallus development showing late formation of rhizoids and short germ tube continuous with sporangium proper; Figs. 13-17, thallus development showing pronounced germ tube walled off from sporangium proper; Fig.18, emergence of zoospore mass with operculum detached; Fig. 19, opercula at various levels of focus. Outline of lens paper fiber shown in Figs.5-10, 13-14. Figs. 1-10, 13-14, to scale a, all others to scale $b$ 


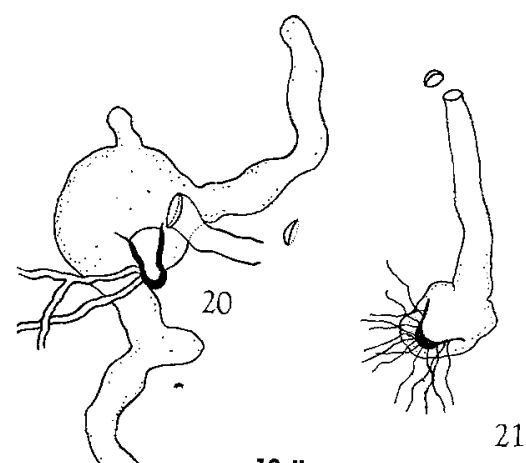

21

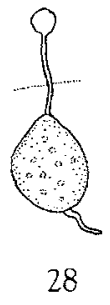

27

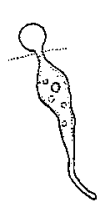

26

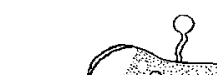

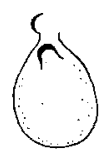

22

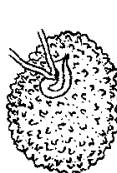

24

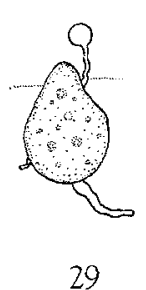

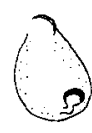

23

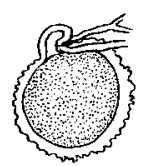

25

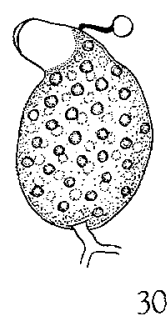

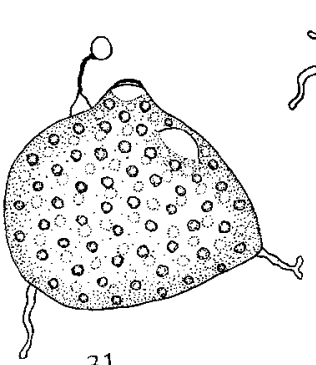

31 कo. 000 oo 000 100000000 10000000 o. o o o 00 o. 0.0000 $\int_{\Omega}^{0.00 \%}$ 32

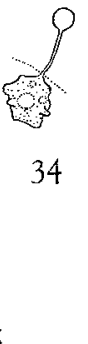

35

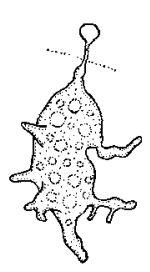

36
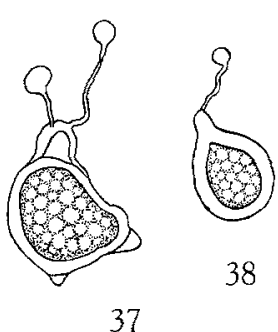

38

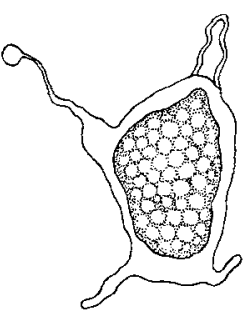

39

Plate II 
flagellum $17.0 \mu$ long; released en masse by the dehiscence of $4.0-6.0 \mu$ diameter opercula capping one to five papillae or discharge tubes $8.0-27.0 \mu \times 6.5 \rightarrow 17.0 \mu$; held quiescent for some time at the orifice by the extruded gelatinous substance formed beneath the operculum. Endooperculum and vesicle not formed. Resting spores borne like the sporangium, spherical or oval, $15.0-23.5 \mu \times 10.0-13.5 \mu$, with globular content and light brown $1.5-2.0 \mu$ thick wall with or without blunt spines or tubercles $2.0-7.0 \mu \times 1.5-2.0 \mu$ at the base; germination not observed.

On lens paper and cellophane bait in culture dishes of forest soil and leaf litter samples, Grapevine Point (type locality), vicinity of the Biological Station, University of Michigan, Cheboygan Co., 12 June, 1968; Johnson Rd. near "Antique Bog", Emmet Co., 13 June, 1968; Big Bay, Marquette Co., 5 July, 1968, coll. Dr. H. Threns; vicinity of Round Lake, Mackinaw Co., $10 \mathrm{July,} \mathrm{1968,} \mathrm{coll.}$ W. PATRxok, all in Michigan, U.S.A.

The development of this chytrid is essentially the same as in other congeneric forms, and is illustrated in Figs. 26-39. One peculiarity of $E$. cystarum is the persistence of the non-functional, empty zoospore case throughout the entire development of both the sporangial (Figs.27-33) and resting spore (Figs. 34-39) thalli. So far as is known only one species of Endochytrium, namely, E. pseudodistomum (Scherffel) KarLING (1941 b), has this feature. The Michigan fungus differs, however, from Scherffel's fungus in several essentials. Whereas E. pseudodistomum has strongly developed, much-branched rhizoids, larger zoospores $(\tilde{\mathbf{s}} .0-7.5 \mu$ in diameter), and spherical resting spores with reflexed scales on the surface, $E$. cystarum has depauperate, simple to twice branched, poorly developed rhizoids (Figs. 31-33), smaller zoospores $(2.2-2.6 \mu$ in diameter, Fig. 26), and smooth, tuberculate, or spiny resting spores (Figs. 37-39). Perhaps less significant, E. pseudodistomum has so far been found only in filaments of Spirogyra and Zygnema, whereas $E$. cystarum has been grown on lens paper and less luxuriantly on cellophane bait. Trials to infect filaments of Spirogyra sp. gave negative results.

The multiple attachment of the rhizoids in E. cystarum (Figs.31,32) is also found in some thalli of Endochytrium operculatum (de Wild.) KARLING (1937) and in species of Entophlyetis. The poorly developed

Plake II. Figs. 20-25, Endochytrizm muliguttulaium n. sp. Fig. 20, empty sporangium with four discharge tubes only one of which is functional; Fig.21, unusual empty sporangium with hair-like processes arising from thickened portion of zoospore cyst; Figs. 22-23, empty sporangia similar to that in Fig. 11 with hinged opercula ; rhizoids omitted; Figs.24-25, surface view and optical section of resting spores. Figs.26-39, Endochytrium cystarum n. sp. Fig. 26, zoospores; Figs.27-29, early stages of sporangial development; Figs.30-32, mature sporangia with persistent zoospore cyst, germ tube, and depauperate rhizoidal system; Fig.33, empty sporangium with three discharge tubes and detached opercula; Figs. 34-36, early stages of resting spore development; Fig.37, sexually formed (?) mature resting spore; Figs.38-39, mature resting spores. Outline of lens paper fiber shown in Figs. $27-29,34-36$. Figs, $20-25$ to scale b, all others to scale a 
rhizoidal system in $E$. cystarum, however, is a sharp departure from the typically extensive, much-branched, and often polyphagous rhizoids in all other known species of Endochytrium, most of which occur in the Characeae and in filaments of other green algae. Interestingly, there seems to be no question but that the depauperate rhizoids of $E$. cystarum are efficient enough to nourish to maturity a $90.0 \mu$ in diameter sporangium, if, indeed, only these structures function in absorption. An intriguing case is presented by some thalli where no traces of any kind of food gathering system have been found, even with stained preparations. In this instance, it is possible that the nutriments are absorbed directly by the thin-walled sporangium, as is the case in Olpidium, Olpidiopsis, and other endobiotic holocarpic forms. Another possible interpretation, though less likely, is that the rhizoids, very delicate looking as they are, could have been shed and later disintegrated before the thallus reached maturity. This has been reported for Entophlyctis reticulospora Cook (1966) in Closterium, and perhaps is the case also in the not too well-known Endochytrium oophilum SPARRow (1933) in rotifer eggs.

What appear to be cases of sexuality were observed in a few mature resting spores (Fig. 37). Whether these are apparent or real could not be ascertained since the resting spores, as well as the sporangia, often occur in clusters in the substratum (lens paper).

Diplophlyctis buttermerense (Willoughby) comb. nov.

Nephrochytrium buttermerense Willoughby, Nova Hedwigia $3: 441$, plates 14-16. 1962

On onion skin bait in culture dishes of water samples and decayed vegetables, roadside ditch, Levering Rd., Emmet Co., Michigan, U.S.A., 12 July, 1968.

The identification of the Michigan material with Willoughby's fungus is based on the following similarities: development of the sporangial thallus; presence of a thin-walled, functional empty zoospore case incorporated into the rhizoidal system; shape and dimensions of the zoospores, sporangia, and apophyses; and presence of a sunken "operculum" (endo-operculum) in the discharge tubes of mature sporangia. One noteworthy departure from the original description of $N$. buttermerense is that the hyaline wall of the cup-shaped apophysis (Figs. 44-48) reaches a thickness of $2.0 \mu$ only, in contrast to $7.5 \mu$ in the British material. This, however, is a minor variation; differences in sporangial wall thickness occur commonly in different strains of the same chytrid species, e.g., Rhizophlyctis rosea. Moreover, Willoughby's material grew on cellophane bait, whereas the present strain was on onion skin.

On examination of WILLOUGHBX's plates $14-16$, one is impressed by the sunken "operculum" in the discharge tube, the tip of which is 
open in mature sporangia. WПLоUGHBY did not state how such a curious discharge mechanism is formed, but study of the Michigan strain has shown that in immature sporangia, the tips of the discharge tubes deliquesce progressively to form a plug of a gelatinous consistency (Fig. 40, a-e). Subsequently, the underlying protoplasmic membrane thickens and becomes an endo-operculum in a pattern similar to that reported for Rhizophlyctis rosea, Diplophlyctis amazonensis, and Cladochytrium crassum. The endo-operculum is usually sunken and domeshaped (Figs. 41, 43, 46), pyramidal or umbonate (Fig. 44), and it may occasionally protrude out of the orifice of the discharge tube (Figs.42,45).

As in Diplophlyctis amazonensis (Karling) Sparrow (KARLING, 1944a), the apical slimy plug dissolves completely during zoospore differentiation. In mature sporangia, the orifice of the discharge tube is left opened (Figs. 42-43), with only the endo-operculum protecting the zoospores until these are released. Dehiscence is also as in $D$. amazonensis, the endo-operculum being either displaced or carried up and capping the slowly emerging mass of initially immobile zoospores. No definite pythiaceous type of vesicle has been noted, but the ball of zoospores is temporarily held together by the extruded gelatinous substance formed beneath the endo-operculum (Figs. 43, 46).

While the endo-operculum is a constant feature of the mature sporangia of $N$. buttermerense, it is not to be regarded, in the strict sense, as a true operculum, that is, a discrete and integral part of the sporangial wall (Haskins, 1950; Sparrow, 1960). For this reason, WrLLoughbY's species is best placed in Diplophlyctis. A slight broadening of our present generic concept of Diplophlyctis is necessary to include this species, as well as those recently described ones with a zoospore cyst persisting as a stalked or sessile appendage on the sporangium [D. chitinophilum WILLOUGHBY (1962a), D. nephrochytriodes KaRLING (1967a), and Nephrochytrium complicatum WسLougнвт (1962b)]. The last-named fungus should, as KARLING (1967a) implies, likewise be referred to Diplophlyctis because of its inoperculate dehiscence. This change is not effected here due to the lack of material for study.

Diplophlyctis bultermerense is a morphologically close ally of $D$. amazonensis, but it is distinguished from the latter on the basis of the insertion of the zoospore cyst in developing thalli. In the former, the cyst is a functional part of the rhizoidal system and is usually attached to the apophysis (Figs. $44-47$ ). In $D$. amazonensis, the cyst is attached directly to the young sporangium and it disappears as the latter structure matures (KARLING, 1944a). The resting spores are spiny in both species, but in $D$. buttermerense these--not reported by W\#LOUGHBY - are developed and borne like the sporangia, are golden-brown, and are invariably spherical (Fig. 48). In D. amazonensis, on the other hand, they have 
no attached empty zoospore cyst, and KARLING qualified them as dark brown and "usually oval and somewhat bean-shaped". No evidence of sexuality similar to that attributed by SPARRow (1936) to D. intestina

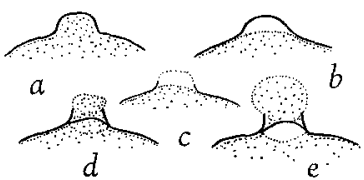

40

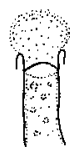

41

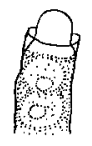

42

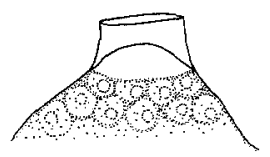

43

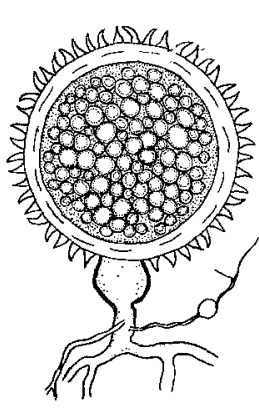

48
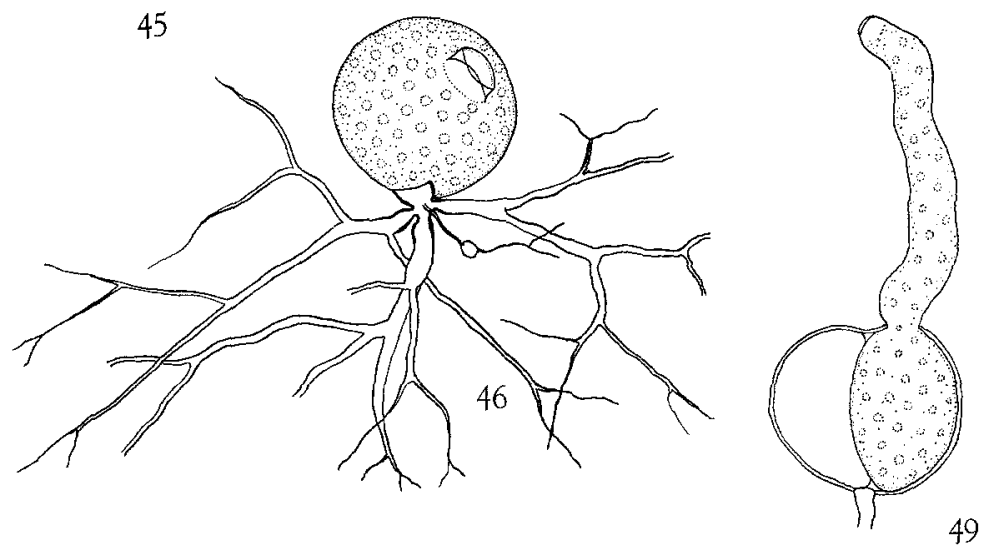

Plate III 
(Schenk) Schroeter, or to the unusual gametic fusion reported by HaSkINS (1950) for $D$. sexualis, has been found in $D$. buttermerense.

The Esthwaite Water fungus referred to D. amazonensis by WILLOUGHBY (1961, his Fig. $6, \mathrm{~h}-\mathrm{n}$ ) is apparently $D$. buttermerense on the strength of the persistent zoospore cyst in the rhizoidal system of both sporangial and resting spore thalli. WILLOUGHBY interpreted this cyst as a case of "rhizoidal catenulation".

\section{(?) Solutoparies sp.}

In association with Rhizophydium spinosum on lens paper bait eroded by Rhizophlyctis rosea and bacterial action, in culture dishes of soil and leaf litter samples, Grapevine Point, vicinity of Biological Station, Univ. of Michigan, Cheboygan Co., Michigan, U.S. A., 12 June, 1968.

The stipitate sporangia are hyaline, thin-walled, spherical (Fig. 52), $12.0-35.0 \mu$ in diameter, or obovoid (Figs. 50-51), 11.0-15.0 $\mu$ high by $8.0-10.0 \mu$ broad, and with numerous blunt spear-or cone-shaped spines scattered on the upper two-thirds of the sporangium, the basal portion of which is completely smooth. The spines are of solid wall material, up to $4.0 \mu$ high by $2.0 \mu$ broad at their convex base (Fig. 54). The rhizoidal system consists of an up to $70.0 \mu$ long, subsporangial main extramatrical stalk which becomes divided distally into sparingly branched, tapering rhizoids (Figs. 54, 56). The stalk may be isodiametric throughout, or with a slight swelling a short distance from the base of the sporangium (Figs. 52-53). The relationship of the intramatrical rhizoids of the Solutoparies with those of its apparent host, Rhizophlyctis rosea, was not ascertained. Whether or not they penetrate or merely envelope the outside of the rhizoids of $R$. rosea is not known for sure. The $R$. rosea matures and releases its zoospores in the absence, as well as in the presence, of the Solutoparies.

The zoospores in mature sporangia apparently have a single globule (Fig. 52). Actual zoospore release, however, was not seen in spite of prolonged observations. Fortunately, some information was gained, though fragmentary, on how this is accomplished. As shown in Fig. 53,

Plate III. Figs.40-48, Diplophlyctis buttermerense (Willoughby) comb. nov. Figs.40, a-e, stages in development of gelatinous plug and endo-operculum; Fig.41, discharge tube of an immature sporangium with gelatinous plug, sunken endo-operculum, and reflexed orifice; Figs.42-43, variations in shape and extent of endo-operculum in mature sporangia with open orifice; Figs.44-46, immature and mature sporangia; Fig.47, empty sporangium; note collar-like remnant of endo-opereulum in the discharge tube; Fig.48, mature resting spore. Fig.49, Nowakowskiella hemisphaerospora, germinated resting spore and attendant "male cell". Note rhizoid-incorporated zoospore cysts in Figs.44-48. Figs.42-43, 48, 49, to scale $a$, all others to scale $b$ 
the zoospores are apparently liberated upon the dissolution of the sporangial wall of the spiny portion of the sporangium. All that is left

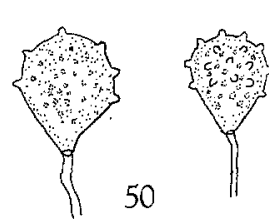

51

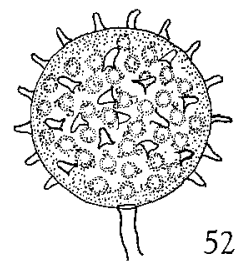

52

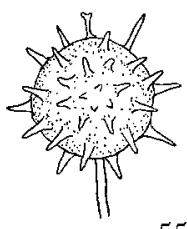

55

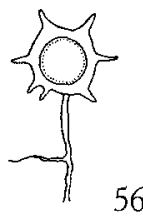

56
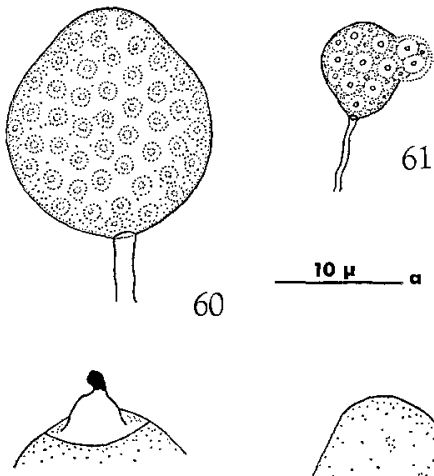

64

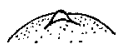

65

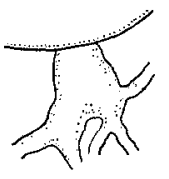

68

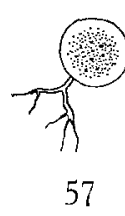

57

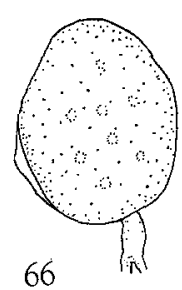

69

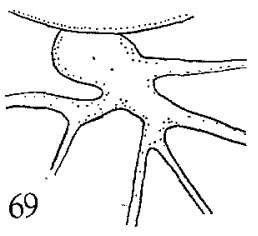

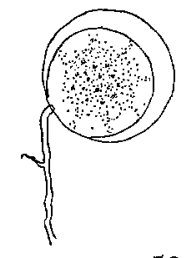

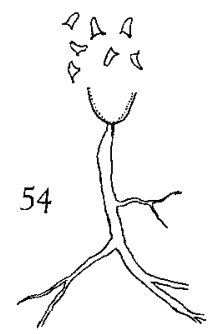

58

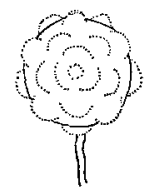

59

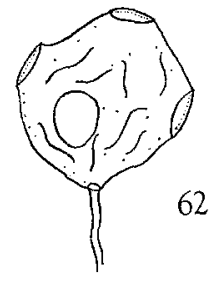

62
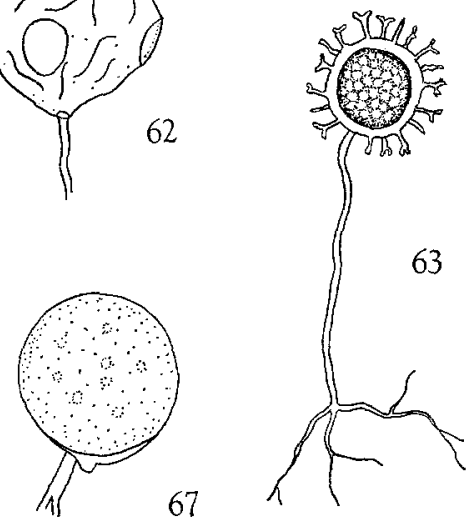

70

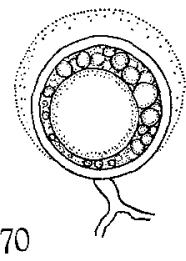

Plate IV 
then of the original sporangium is its smooth basal portion around which are scattered the intact spines (Fig. 54).

Associated with the sporangial thalli were numerous spiny, goldenbrown, thick-walled, spherical resting spores, $8.0-16.0 \mu$ in diameter (including the spines), borne like the sporangium, and with a single, big oil globule (Figs. 55-56). It is fairly certain that these resting spores belong to the Solutoparies although they were found associated with the more luxuriantly growing Rhizophydium spinosum. The evidence to this effect is purely circumstantial since all previously examined Solutoparies-free cultures of $R$. spinosum had multiguttulate resting spores (Fig. 63).

This bizarre Michigan chytrid is placed tentatively in WHIFEEN's (1942) monotypic genus, Solutoparies. It is very similar to $S$. Pythii Whiffen on the basis of sporangial shape, size, and ornamentation, and perhaps even in the method of dehiscence, when this is substantiated by further studies. Judging from WHIFFEN's illustrations, the sporangial spines in $S$. Pythii are also solid, but these were reported to had undergone a process of dissolution before the zoospores initiated motility. No resting spores have as yet been reported for her species, and the sporangial thalli, cultured on Pythium sp. on "hemp seed in water and on agar" were said to be "entirely extramatrical".

WILlodghby's (1965) "monocentric sp. 2" (his Fig. 4, n-o) is probably identical with the Michigan fungus.

\section{Rhizophydium spinosum Willoughby}

On cellophane and lens paper bait eroded by either Rhizophlyctis rosea, Rhizophydium coronum, Endochytrium cystarum, or by bacterial action, in culture dishes of forest soil and leaf litter samples, Grapevine Point, Cheboygan Co., 12 June 1967, 22 July 1968; Johnson Rd. near "Antique Bog", Emmet Co., 13 June 1968; vicinity of Round Lake, MacKinaw Co., 10 July 1968, coll. W. PAтrick, all in Michigan, U.S.A.; edge of Silver Lake, Raleigh, North Carolina, U.S.A., May 1968,

Plate IV. Figs.50-56, (?) Solutoparies sp. Figs. 50-51, young sporangia; Fig. 52, mature sporangium with spine-free basal portion; Figs.53-54, fate of sporangial wall and spines after zoospore discharge; Figs.55-56, surface view and optical section of mature resting spores. Figs. 57-63, Rhizophydium spinosum. Figs. 57-58, young sporangia with characteristic granulation of content; Fig.59, schematic representation of a nearly mature sporangium with localized slimy exudate on surface; Fig.60, mature sporangium, discharge papilla(e) not visible; Fig.61, beginning of zoospore discharge; Fig.62, empty sporangium with dilated pores; Fig. 63, mature resting spore thallus. Figs. 64-70, Rhizophydium coronum. Fig. 64, portion of sporangium formed by enlargement of germ tube; Figs.65-67, unilaterally developed immature sporangia with "halo" omitted; Figs.68-69, basal portion of sporangia with apophysate rhizoidal system; Fig.70, resting spore with unilayered "halo". Fig. 59, freehand drawing, all others to scale 
coll. Mr. and Mrs. A. Qutnio; vicinity of the Univ. of Manitoba Field Station, Delta, Manitoba, Canada, July 1968, coll. Miss. N. Ordiddo; Suburb garden, Monrovia, Liberia, 18 October 1962; Hill above Yaounde, Cameroon, 14 November 1962, African oil palm plantation near Conception, Fernando Poo, 14 November 1962; all in Africa, coll. A. G. Kevorkian; Rungoon City Park, Rangoon, Burma, May 1967, coll. Mr. D. Rirynolds; edge of rice paddies, Batangas Province, Philippines, June 1968, coll. Miss. Z. Toquero.

This is an apparently common soil chytrid, particularly in forest and uncultivated soils. It has been hitherto known only from the Australian material described by Willoughiy (1965). The specimens from the above-listed places agree well with WILLOUGHBY's and will not be described in any great detail here, except where added information has been obtained.

Staining with cotton blue solution showed that $R$. spinosum is not parasitic on any of the other chytrids with which it was found on cellulosic sustrates. Fibers of the lens paper bait free of chytrid or any other fungal hyphae or rhizoids, but showing signs of bacterial decomposition, also supported growth of $R$. spinosum. This chytrid undoubtedly subsists on the by-products of cellulytic decomposition effected by Rhizophlyctis rosea, bacteria, and the like.

One outstanding feature of $R$. spinosum is its long stalk on which is borne a sporangium or resting spore (Fig. 63). This extramatrical stalk is often isodiametric, up to $1.5 \mu$ broad, and with a few short lateral extensions. The rhizoidal system, however, is best seen in those thalli growing a short distance from the substratum (Fig. 57). Some thalli of the strain from North Carolina had unevenly thickened wall (Fig.58). How zoospore release is accomplished in such thalli, if they ever become sporangial, is a matter for conjecture. As has been noted by WILLOUGHBY, the immature sporangium has numerous minute globules concentrated at its center (Figs.57-58). Mature sporangia are generally spherical, angular, $6.0-40.0 \mu$ in diameter, or pyriform (Fig. 60), 18.0-23.0 $\mu \times 13.0-15.0 \mu$. The zoospores are released en masse and surrounded by a gelatinous substance (Fig. 61), but no definite vesicle has been demonstrated. The entire process of discharge is so slow that in situ zoospore germination is of common occurrence and may be effected further by the collapse of the sporangium simultaneous with discharge. Motile zoospores are $3.5-4.0 \mu$ in diameter, with a $2.5 \mu$ in diameter globule, and a $20.0 \mu$ long posterior flagellum. The resting spores have globular content and light brown wall elaborated with simple or bifurcate spines (Fig.63).

Rhizophydium spinosum belongs to that small group of species in the genus $-R$. coronum, $R$. stipitatum, $R$. difficile, etc.-characterized by having a slimy exudate around the sporangium, resting spore, or both. In $R$. spinosum, however, the slime exudate does not take the form of a "halo", but rather occurs in localized spots giving the impression of nearly invisible dome-shaped bumps on the surface of the developing sporangium or resting spore. As has been noted by WrLLOUGHBY, slime formation is a preliminary stage in spine formation in the resting spores of $R$. spinosum. In this present study, the aforementioned slime deposit was also noted on several nearly mature sporangia (Fig.59), but it could not be demonstrated in other sporangia of comparable age, even in cotton-blue-stained preparations. Fully mature sporangia likewise lacked the slime which apparently disappeared before or during zoospore cleavage, as in Rhizophydium coronum Hanson.

\section{Rhizophydium coronum Hanson}

On lens paper bait in culture dishes of forest soil samples, Cross Village, Emmet Co., Michigan, U.S.A., 15 July 1968, coll. D. Farr. 
The Michigan material showed some variations from Harsox's (1945) fungus. About $10 \%$ of the observed sporangial thalli were formed by an uneven expansion of the original zoospore cyst. The remnant of the cyst thickened and may be located, with reference to the origin of the rhizoidal system, at the apical, lateral, or sub-basal portion of the sporangium (Figs.65-67). On one occasion, the whole thallus was formed apparently from the germ tube itself (Fig.64). A few thalli were definitely apophysate (Figs. 68-69), and still others, with a rhizoidal system more typical of a Rhizidium. As in the Australian material (WrLlovghry, 1965), no zonation of the gelatinous "halo" around the sporangium or resting spore was ever observed (Fig. 70).

\section{Phlyctochytrium aureliae Ajello}

On onion skin bait in culture dish of decayed Sphagnum, Gates' Bog, Cheboygan Co., Michigan, U.S.A., 24 August 1967.

On this bait the sporangia do not differ from those on shrimp skin, but the apophysis is more distinctive and the sparingly branched rhizoids more tenuous. (See MILLER, 1968.)

\section{Cladochytrium crassum Hillegas}

On lens paper and cellophane bait in culture dishes of garden soils, Ann Arbor, Michigan, April 1968; Harrison Ave., Raleigh, North Carolina, July 1968, coll. Mr. and Mrs. A. Qunmo; Quezon Province, the Philippines, June 1968, coll. Miss. Z. TOQUERo.

All three strains agree well with HItTEGAs' (1941) account. One striking characteristic of this species is the formation of a thin-walled endo-operculum beneath the gelatinous plug at the orifice of the discharge papilla, but the discharge mechanism is still inoperculate.

\section{Nowakowskiella hemisphaerospora Shanor}

On lens paper bait in culture dish of Sphagnum and mud samples, Mud Lake, Cheboygan Co., Michigan, U.S.A., 30 June 1968; on onion skin in culture dishes of soil samples from the Singapore Botanical Gardens, Bukit, Timah, Singapore, and from a farm in Thailand, June 1967, coll. Mr. D. Reynolds.

Trabeculae similar to those in Cladochytrium crassum occurred in the rhizomycelium of the Singapore isolate. These are of a slightly higher refractivity than the side wall itself, and often plug the lumen as in the Leptomitaceae. As many as 13 resting spores may be produced in a single container. On two rare occasions, germination of four resting spores was witnessed in the same Singapore isolate. Each of these functioned as a sporangium (Fig.49). Such type of resting spore germination is not in accord with KARLING's (1967b) earlier observation on a $N$. hemisphaerospora from New Zealand, but this difference is not totally suprising. In $N$. ramosa Butler, for example, KaRLING (1944b) observed both types of resting spore germination.

\section{References}

Cook, P. W.: Entophlyctis reticulospora sp. nov. a parasite of Closterium. Trans. Brit. Mycol. Soc. 49, 545-550 (1966).

Emerson, R.: An experimental study of the life cycles and taxonomy of Allomyces. Lloydia 4, 77-144 (1941). 
Hansox, A. M.: A morphological, developmental, and cytological study of four saprophytic chytrids. II. Rhizophydium coronum Hanson. Amer. J. Bot. 32, $479-487(1945)$.

Haskins, R. H.: Studies in the lower chytridiales. III. Endo-operculation and sexuality in the genus Diplophlyctis. Mycologia (N.Y.) 42, $772-777$ (1950).

HiLleggas, A. B.: Observations on a new species of Cladochytrium. Mycologia (N. Y.) 33, 618-632 (1941).

JoHns, R. M.: Additions to the phycomycete flora of the Douglas Lake region. III. A new species of Scherffeliomyces. Mycologia (N.Y.) 48, 433-438 (1956).

KaRLING, J. S.: The structure, development, identity, and relationship of Endochytrium. Amer. J. Bot. 24, 352-364 (1937).

- Cylindrochytridium johnstonii gen. nov. et sp. nov., and Nowakowskiella profusum sp. nov. Bull. Torrey Bot. Club 68, 381-387 (1941 a).

- Notes on Endochytrium du Plessis. Mycologia (N.Y.) 33, 356-359 (1941 b).

- Brazilian chytrids. III. Nephrochytrium amazonensis. Mycologia (N.Y.) 36, $351-357$ (1944a).

-- Brazilian chytrids. I. Species of Nowakowskiella. Bull. Torrey Bot. Club 71, $374-389$ (1944b).

- Brazilian chytrids. X. New species with sunken opercula. Mycologia (N.Y.) 39, 56-70 (1947).

- Truittella setifera gen. nov. et. sp. nov., a new chytrid from Maryland. Amer. J. Bot. 36, 454-460 (1949).

- Some zoosporic fungi of New Zealand. VI. Entophlyctis, Diplophlyctis, Nephrochytrium and Endochytrium. Sydowia 20, 109-118 (1967a).

- Some zoosporic fungi of New Zealand. VIII. Cladochytriaceae and physodermataceae. Sydowia 20, 129-136 (1967 b).

MTLER, C. E.: Observations concerning taxonomic characteristics in chytridiaceous fungi. J. Elisha Mitchell Sci. Soc. 84, 100-107 (1968).

Paterson, R. A.: Additions to the phycomycete flora of the Douglas Lake region. II. New chytridiaceous fungi. Mycologia (N. Y.) 48, 270-277 (1956).

Sparrow, F. K., JR.: Observations on operculate chytridiaceous fungi collected in the vicinity of Ithaca, N.Y. Amer. J. Bot. 20, 63-77 (1933).

- Evidences for the possible occurrence of sexuality in Diplophlyctis. Mycologia (N. Y.) $28,321-323(1936)$.

- Phycomycetes from the Douglas Lake region of northern Michigan. Mycologia (N.Y.) 44, 759-772 (1952).

- Aquatic phycomycetes. 2nd. ed. Ann Arbor. Michigan: Univ. Mich. Press 1960.

-, and Margaret E. Barr: Additions to the phycomycete flora of the Douglas Lake region. I. New taxa and records. Mycologia (N.Y.) 47, 546-556 (1955).

-, and W. J. Kocre: Additions to the phycomycete flora of the Douglas Lake region. IV. New records and notes for 1956-1967. Pap. Mich. Acad. Sci. 44, 153-161 (1959).

- R. A. Paterson, and R. M. Johns: Additions to the phycomycete flora of the Douglas Lake region. $V$. New or interesting fungi. Mycologia (N.Y.) 50, $115-123(1965)$.

- A new bog chytrid. Arch. Mikrobiol. 53, 178-180 (1966).

WHAFEN, At.M. J.: Cellulose decomposition by the saprophytic chytrids. J. Elisha Mitchell Sci. Soc. 57, $321-330$ (1941).

- Two new chytrid genera. Mycologia (N.Y.) 34, 543-557 (1942).

WiLlougribY, L. G.: The ecology of some lower fungi at Esthwaite Water. Trans. Brit. Mycol. Soc. 44, 305-332 (1961). 
WILloughbY, L. G.: The ecology of some lower fungi in the English Lake district. Trans. Brit. Mycol. Soc. 45, 121-136 (1962a).

- New species of Nephrochytrium from the English Lake district. Nova Hedwigia 3, 439-444 (1962b).

- A study of the distribution of some lower fungi in soil. Nova Hedwigia 7, $133-150$ (1964).

- A study of chytridiales from Victorian and other Australian soils. Arch. Mikrobiol. 52, 101-131 (1965).

IRINEO J. Dogma, JR.

Department of Botany

University of Michigan

Ann Arbor, Michigan, U.S.A. 